\title{
Peningkatan Keterampilan Berpikir Kreatif Melalui Pembelajaran Fisika Berbasis Potensi Lokal
}

\author{
Siti Sarah \\ Pendidikan Fisika, Universitas Sains Al Quran \\ Jl. Raya Kalibeber KM. 03, Wonosobo 56351 \\ st.sarah44@gmail.com
}

\begin{abstract}
Abstrak
Perkembangan teknologi informasi dan komunikasi pada abad 21 berkembang begitu cepat. Oleh karena itu, diperlukan berbagai keterampilan hidup untuk dapat mengimbangi pesatnya perkembangan teknologi, salah satunya keterampilan berpikir kreatif. Keterampilan berpikir kreatif dapat ditumbuhkan melalui pembelajaran fisika berbasis potensi lokal. Penelitian ini bertujuan untuk mengetahui adakah peningkatan keterampilan berpikir kreatif siswa yang melakukan pembelajaran berbasis potensi lokal. Metode penelitian yang digunakan berupa quasi eksperimen. Instrumen yang digunakan adalah tes dan observasi. Analisis data menggunakan analisis deskriptif kuantitatif dan kualitatif. Hasil penelitian menunjukkan bahwa ada peningkatan keterampilan berpikir kreatif siswa yang melakukan pembelajaran fisika berbasis potensi lokal sebesar 0,15975 dengan kategori rendah.
\end{abstract}

Kata kunci: keterampilan berpikir kreatif, pembelajaran fisika, dan potensi lokal

\begin{abstract}
The development of information and communication technology in the 21 st century developed so fast. Therefore, various life skills are needed to be able to keep pace with the rapid development of technology. One of them is creative thinking skills. The skill of creative thinking can be cultivated through local potential physics-based learning. This study aims to determine whether there is an increase in creative thinking skills of students who conduct local potential based learning. The research method used was quasi experiment. The instruments used were tests and observation sheets. Data analysis used quantitative and qualitative descriptive analysis. The results showed that there is an increase in creative thinking skills of students who conducted physics learning based on local potential of 0.15975 in the low category.
\end{abstract}

Keywords: creative thinking skills, physics learning, local potential

\section{PENDAHULUAN}

Abad 21 merupakan masa dimana perkembangan teknologi informasi dan komunikasi berkembang semakin cepat. Hal ini berimbas pada semakin pesatnya perubahan zaman. Oleh karena itu, diperlukan berbagai keterampilan yang disiapkan bagi siswa untuk dapat hidup di abad 21. Menurut Trilling \& Fadel (2009) keterampilan abad 21 terbagi atas 3 kelompok, yaitu life and career skills, learning and innovation skills, dan information media and technologi skill. Jika ditelaah secara lebih mendalam ketiga kelompok keterampilan tersebut membutuhkan keterampilan berpikir kreatif. Melalui keterampilan kreatif, masyarakat dapat mengimbangi perkembangan zaman yang begitu cepat di abad 21. Salah satu ciri dimilikinya keterampilan berpikir kreatif adalah diakomodirnya kemampuan tersebut dalam pekerjaan. Hal ini dikarenakan bahwa berpikir kreatif memungkinkan pemecahan masalah di berbagai bidang, menciptakan solusi yang inovatif, asli, dan berkualitas (Udi \& Amit, 2011; Meintjes \& Grosser, 2010; Erdogan, Akkaya \& Akkaya, 2009). Artinya, semakin banyak orang yang memiliki keterampilan berpikir kreatif maka semakin banyak inovasi dan produk berkualitas dihasilkan. Jika suatu negara memiliki masyarakat dengan tingkat keterampilan berpikir kreatif tinggi, maka angka pengangguran pun semakin kecil.

Meskipun demikian, harapan dimilikinya masyarakat yang memiliki keterampilan 
berpikir kreatif tinggi belumlah sejalan dengan kenyataan yang ada. Hal ini dapat dilihat dari data ketenagakerjaan di Indonesia.

Tabel 1. Persentase penyerapan tenaga kerja berdasarkan tingkat pendidikan di Indonesia

\begin{tabular}{lcc}
\hline \multicolumn{1}{c}{ Tingkat Pendidikan } & $\begin{array}{c}\text { Februari } \\
2017\end{array}$ & $\begin{array}{c}\text { Februari } \\
2018\end{array}$ \\
\hline $\begin{array}{l}\text { Rendah (SMP ke } \\
\text { bawah) }\end{array}$ & $60,27 \%$ & $59,68 \%$ \\
$\begin{array}{l}\text { Sedang (SMA } \\
\text { sederajat) }\end{array}$ & $27,35 \%$ & $28,23 \%$ \\
$\begin{array}{l}\text { Tinggi (Diploma dan } \\
\text { Universitas) }\end{array}$ & $12,26 \%$ & $11,97 \%$ \\
\hline \multicolumn{2}{c}{ Sumber: Badan Pusat Statistik (2018) }
\end{tabular}

Tabel 2. Persentase jumlah pekerja penuh dan tidak penuh waktu di Indonesia

\begin{tabular}{lcc}
\hline & Februari & Februari \\
& 2017 & 2018 \\
\hline $\begin{array}{l}\text { Pekerja penuh } \\
\begin{array}{l}\text { Pekerja tidak } \\
\text { penuh }\end{array}\end{array}$ & $69,86 \%$ & $68,53 \%$ \\
\hline \multicolumn{3}{c}{ Sumber: Badan Pusat Statistik (2018) }
\end{tabular}

Tabel 1 menunjukkan bahwa tidak terjadi penyerapan tenaga kerja pada penduduk Indonesia dengan tingkat pendidikan tinggi dan menengah. Tabel 2 mempertegas Tabel 1 bahwa tenaga kerja Indonesia yang bekerja pun bukanlah pekerja yang memiliki produktivitas tinggi. Data ini menunjukkan bahwa masih sedikit masyarakat yang memiliki keterampilan berpikir kreatif. Oleh karena itu, berbagai usaha diperlukan untuk menciptakan masyarakat yang memiliki keterampilan berpikir kreatif guna meningkatkan kesejahteranan manusia. Masyarakat yang dibiarkan tanpa memiliki keterampilan berpikir kreatif akan menimbulkan masalah baru, yaitu kemiskinan. Bertambahnya tingkat kemiskinan dapat menyebabkan meningkatnya kriminalitas. Oleh karena itu, sebelum terlambat ini harus dicegah. Salah satu caranya yaitu dengan mengintegrasikan keterampilan berpikir kreatif dalam pembelajaran di sekolah.

Fisika merupakan cabang IPA yang mendasari perkembangan teknologi maju dan konsep hidup harmonis dengan alam. Collette \& Chiappetta (1994: 30) menyatakan bahwa sains terbentuk dari sikap ilmiah, proses ilmiah, dan produk ilmiah. Artinya, produk sains terbentuk melalui proses ilmiah yang panjang hingga melahirkan produk ilmiah dan sikap ilmiah dari pelaku yang melaksanakan proses sains. Secara khusus, Giancoli (2011: 2) mendefinisikan fisika sebagai aktivitas kreatif yang dalam banyak aspeknya menyerupai aktivitas-aktivitas kreatif lain. Salah satu aspek penting dalam sains adalah pengamatan dan observasi terhadap kejadiankejadian, meliputi perencanaan dan pelaksanaan eksperimen. Dengan demikian, seorang ilmuwan harus melakukan aktivitasnya secara kreatif untuk mencapai tujuan yaitu menghasilkan produk ilmiah dan sikap ilmiah. Melalui aktivitas kreatif inilah, siswa selama pembelajaran fisika dilatih untuk memiliki keterampilan berpikir kreatif. Harapannya, akan terbentuk keterampilan berpikir kreatif dalam diri siswa sejak kecil.

Meskipun demikian, membelajarkan fisika bukanlah hal mudah. Banyak kajian dilakukan dengan tujuan menemukan cara dalam membelajarkan fisika sehingga mudah dipelajari, seperti dilakukan Klieger \& Sherman (2015) dan Scheider (1980). Mencermati beberapa hasil penelitian di atas, ada banyak faktor yang menentukan keberhasilan siswa dalam mempelajari fisika. Namun, jika dilihat dari sisi siswa semua faktor mengerucut pada satu hal yaitu keterlibatan siswa dalam pembelajaran. Keterlibatan siswa meliputi mengamati, meraba, mencoba, hingga menganalisis hasil percobaan. Keterlibatan siswa dalam pembelajaran akan semakin bertambah jika siswa langsung melihat aplikasi fisika dengan potensi lokal yang dimiliki tempat siswa tinggal. Ada 5 keunggulan pendidikan yang mengintegrasikan potensi lokal, yaitu (1) relevan dengan dunia nyata, (2) membekali kompetensi spesifik siswa sebagai life skill, (3) mendorong lahirnya kreativitas, (4) mendorong lahirnya entrepreneur profesional, dan (5) mendorong kerja sama dengan masyarakat (Asmani, 2012). Berdasarkan kajian di atas, penelitian ini dilakukan untuk mengetahui adakah peningkatan keterampilan berpikir kreatif siswa yang melakukan pembelajaran berbasis potensi lokal. Penelitian ini mengambil bahasan fluida statis dan potensi lokal di Kabupaten Wonosobo, yaitu Kawah 
Sikidang. Penentuan materi fluida statis dan kawah Sikidaing dikarenakan ada keterkaitan bahwa Kawah Sikidang mengandung belerang yang jika ditelaah dari sisi materi fluida statis ada bahasan viskositas di dalamnya. Berdasarkan keterangan guru fisika di MAN 1 Wonosobo, pembahasan mengenai fluida statis jarang dilakukan dalam bentuk praktikum dengan alasan alat laboratorium yang kurang memadai dan rendahnya tingkat kemandirian siswa dalam melakukan praktikum. Hal ini menjadikan guru tidak mau mengambil resiko mengadakan praktikum. Padahal praktikum merupakan salah satu cara untuk mencapai keterampilan berpikir kreatif oleh siswa.

\section{METODE/EKSPERIMEN}

Metode penelitian yang akan digunakan berupa quasi eksperimen, yaitu control-group pre-test post-test design. Berikut desainnya.

\begin{tabular}{|l|l|l|l|}
\hline $\begin{array}{l}\text { Kelas Eksperimen } \\
(\mathrm{KE})\end{array}$ & Pretest & $\mathrm{X} 1$ & Postest \\
\hline Kelas Kontrol (KK) & Pretest & $\mathrm{X} 2$ & Postest \\
\hline
\end{tabular}

Gambar 1. Desain penelitian

Variabel bebas berupa pembelajaran fisika berbasis potensi lokal. Adapun variabel terikat berupa keterampilan berpikir kreatif siswa. Objek penelitian adalah keterampilan berpikir kreatif. Penelitian dilakukan bulan Oktober 2018 di MAN 1 Wonosobo. Metode pengumpulan data yang digunakan yaitu tes dan observasi. Teknik analisis data dalam penelitian berupa analisis deskriptif kuantitatif dan kualitatif. Analisis deskriptif kuantitatif meliputi analisis pendahuluan, analisis uji prasyarat, uji hipotesis, dan uji lanjut. Analisis pendahuluan meliputi (a) uji validitas dan reliabilitas tes, (b) uji kemampuan awal siswa yang akan digunakan sebagai kelas eksperimen dan kelas kontrol. Uji prasyarat analisis meliputi (a) uji normalitas dan (b) uji homogenitas. Uji hipotesis untuk mengetahui adakah perbedaan keterampilan berpikir kreatif siswa yang belajar menggunakan perangkat pembelajaran fisika berbasis potensi lokal dan siswa yang tidak menggunakannya. Uji hipotesis dikenakan pada data yang dihasilkan dari instrumen tes dan lembar observasi. Uji lanjut untuk mengetahui seberapa besar peningkatan keterampilan berpikir kreatif siswa yang melakukan pembelajaran fisika berbasis potensi lokal sub bahasan Fluida Statis menggunakan uji gain ternormalisasi dengan persamaan sebagai berikut.

$$
<g>=\frac{<S_{f}>-<S_{i}>}{100-<S_{i}>}
$$

Keterangan:

$\langle\mathrm{g}\rangle \quad=$ nilai gain ternormalisasi

$\left.<\mathrm{S}_{f}\right\rangle=$ Skor rata-rata akhir yang diperoleh (postest)

$\langle\mathrm{S}\rangle=$ Skor rata-rata awal yang diperoleh (pretest)

Hasil perhitungan gain ternormalisasi kemudian diinterpretasikan menggunakan klasifikasi dari Hake (1998:65) sebagai table 3.

Tabel 3. Klasifikasi nilai gain ternormalisasi

\begin{tabular}{cc}
\hline Gain ternormalisasi & Interpretasi \\
\hline$<\mathrm{g}>\geq 0,7$ & Tinggi \\
$0,7><\mathrm{g}>\geq 0,3$ & Sedang \\
$<\mathrm{g}><0,3$ & Rendah \\
\hline
\end{tabular}

Analisis deskriptif kualitatif berupa analisis data hasil observasi menggunakan teknik prosentase.

\section{HASIL DAN PEMBAHASAN}

Hasil penelitian terbagi atas 2 analisis, yaitu analisis deskriptif kuantitatif dan deskriptif kualitatif. Analisis deskriptif kuantitatif terdiri dari uji pendahuluan, uji prasyarat, uji hipotesis, dan uji lanjut. Analisis dekriptif kualitatif berupa prosentase jumlah siswa dengan kriteria keterampilan berpikir kreatif tertentu berdasarkan data hasil observasi.

\section{Hasil Analisis Kuantitatif}

\section{Uji Pendahuluan}

Uji pendahuluan berupa uji kesamaan rata-rata dua kelas yang akan dijadikan kelas kontrol dan kelas eksperimen. Uji yang digunakan adalah independent samples test. 
Berdasarkan Tabel 4, diketahui bahwa nilai signifikansi lebih besar dari $0,05(p>0,05)$ yaitu sebesar 0,062 . Artinya, dua kelas yang diambil sebagai kelas eksperimen (KE) dan kelas kontrol $(\mathrm{KK})$ memiliki kesamaan rata-rata yang sama secara signifikan. Oleh karena itu, kedua kelas memenuhi syarat untuk dijadikan sebagai KK dan KE dalam penelitian.

Table 4. Hasil analisis independent sample test data keterampilan berpikir kreatif siswa

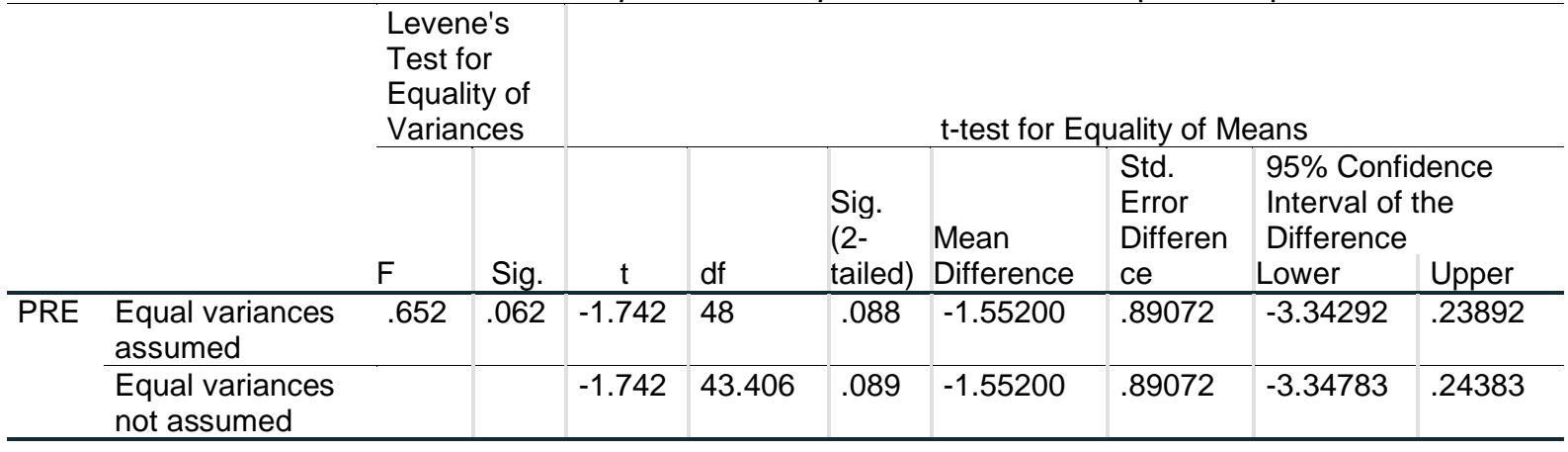

\section{Uji Prasyarat Analisis}

Uji yang digunakan meliputi uji normalitas dan homogenitas.

a. Uji Normalitas

Berikut hasil uji normalitas dari data keterampilan berpikir kreatif siswa

Tabel 5. Hasil uji normalitas keterampilan berpikir kratif siswa

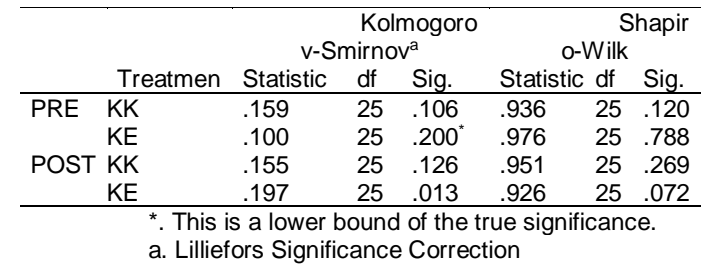

Berdasarkan Tabel 5. diketahui bahwa melalui uji Shapiro-Wilk dapat dilihat bahwa semua data ketrampilan berpikir kreatif memiliki taraf signifikansi lebih besar dari $0,05(p>0,05)$, yaitu 0,120 ; 0,$788 ; 0,269 ;$ dan 0,072 . Artinya, data pretest maupun data posttest berasal dari populasi yang terdistribusi normal.

b. Uji homogenitas

Hasil uji homogenitas dapat dilihat pada tabel 6. Berdasarkan Tabel 6 nilai signifikansi semua analisis lebih besar dari $0,05(p>0,05)$. Artinya, semua data berasal dari populasi yang homogen. Karena uji normalitas dan homogenitas terpenuhi, maka dilanjutkan dengan uji beda menggunakan analisis data parametris.

Tabel 6. Hasil uji homogenitas keterampilan berpikir kratif siswa

\begin{tabular}{llclll}
\hline & $\begin{array}{c}\text { Levene } \\
\text { Statistic }\end{array}$ & df1 & df2 & Sig. \\
\hline PRE & Based on Mean & 3.652 & 1 & 48 & .062 \\
Based on Median & 3.284 & 1 & 48 & .076 \\
$\begin{array}{l}\text { Based on Median } \\
\text { and with adjusted }\end{array}$ & 3.284 & 1 & 44.678 & .077 \\
df & & & & \\
$\begin{array}{l}\text { Based on trimmed } \\
\text { mean }\end{array}$ & 3.580 & 1 & 48 & .065 \\
\hline POST Based on Mean & .061 & 1 & 48 & .806 \\
$\begin{array}{l}\text { Based on Median } \\
\text { Based on Median } \\
\text { and with adjusted } \\
\text { df }\end{array}$ & .042 & 1 & 48 & .838 \\
$\begin{array}{l}\text { Based on trimmed } \\
\text { mean }\end{array}$ & .050 & 1 & 47.862 & .838 \\
\hline
\end{tabular}

\section{Uji Hipotesis}

Uji yang digunakan adalah uji t-test paired sample. Hasilnya sebagaimana pada table 7.

Tabel 7. Hasil uji t-test paried sample keterampilan berpikir kreatif siswa

\begin{tabular}{|c|c|c|c|c|c|c|c|c|}
\hline & \multicolumn{5}{|c|}{ Paired Differences } & \multirow[b]{2}{*}{$\mathrm{t}$} & \multirow[b]{2}{*}{ df } & \multirow[b]{2}{*}{$\begin{array}{l}\text { Sig. }(2- \\
\text { tailed) }\end{array}$} \\
\hline & Mean & $\begin{array}{l}\text { Std. } \\
\text { Deviation }\end{array}$ & $\begin{array}{l}\text { Std. Error } \\
\text { Mean }\end{array}$ & $\begin{array}{l}95 \% \text { Confid } \\
\text { the Differen } \\
\text { Lower }\end{array}$ & $\begin{array}{l}\text { Ice Interval of } \\
\text { Upper }\end{array}$ & & & \\
\hline $\begin{array}{ll}\text { Pair } & \text { KK_POST - } \\
1 & \text { KE_POST }\end{array}$ & -8.70000 & 4.40521 & .88104 & -10.51838 & -6.88162 & -9.875 & 24 & .000 \\
\hline
\end{tabular}


Berdasarkan Tabel 7, dapat diketahui bahwa data postest ketrampilan berpikir kreatif memiliki taraf signifikansi $p<0,05$, yaitu sebesar 0,000. Artinya, terdapat perbedaan ketrampilan berpikir kreatif antara siswa yang mempelajari siswa menggunakan perangkat pembelajaran berbasis potensi lokal dibanding siswa yang belajar fisika tanpa menggunakan perangkat pembelajaran fisika berbasis potensi lokal.

\section{Uji Lanjut}

Uji lanjut menggunakan uji gain ternormalisasi untuk mengetahui seberapa besar peningkatan keterampilan berpikir kreatif.

Tabel 8. Hasil uji gain ternormalisasi

\begin{tabular}{cc}
\hline \multicolumn{2}{c}{ Hasil uji gain ternormalisasi } \\
\hline Kelas eksperimen & Kelas kontrol \\
0,15975 & 0,0802 \\
\hline
\end{tabular}

Berdasarkan uji gain ternormalisasi diketahui bahwa peningkatan keterampilan berpikir kreatif siswa yang melakukan pembelajaran fisika berbasis potensi lokal lebih besar dibanding peningkatan keterampilan berpikir kreatif siswa yang belajar tanpa menggunakan perangkat pembelajaran fisika berbasis potensi lokal. Indikator keterampilan berpikir kreatif yang digunakan dalam penelitian ini meliputi: mengungkapkan pendapat/ide untuk menyelesaikan masalah, menyelesaikan masalah dengan baik, menghasilkan gagasan/ide yang bervariasi untuk menyelesaikan masalah, menyelesaikan masalah dengan berbagai cara, menghasilkan ide yang berbeda dengan yang ada di buku atau pendapat orang lain, menyelesaikan masalah dengan melakukan langkah-langkah terperinci, melakukan percobaan untuk menyelesaikan masalah, dan menunjukkan rasa empati terhadap orang lain. Gambar 5 berikut dapat memberi informasi tambahan mengenai peningkatan keterampilan berpikir kreatif siswa yang telah melakukan pembelajaran fisika berbasis potensi lokal.

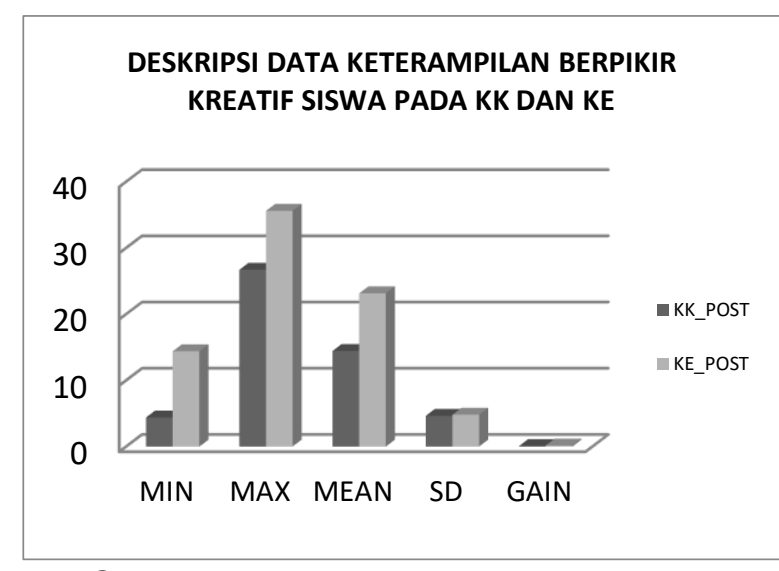

Gambar 2. Deskripsi data peningkatan keterampilan berpikir kreatif siswa KK dan KE

\section{Hasil Analisis Kualitatif}

Analisis kualitatif data keterampilan berpikir kreatif berpedoman pada kriteria berikut.

Tabel 9. Kriteria keterampilan berpikir kreatif

\begin{tabular}{lcl}
\hline \multicolumn{1}{c}{ Rentang skor } & Interpretasi \\
\hline $\mathrm{X} \geq \bar{X}+1 \mathrm{SBi}$ & Sangat Baik & $(\mathrm{SB})$ \\
$\bar{X}+1 \mathrm{SBi}>\mathrm{X} \geq \bar{X}$ & Baik & $(\mathrm{B})$ \\
$\bar{X}>\mathrm{X}>\bar{X}-1 . \mathrm{SBi}$ & Kurang Baik & $(\mathrm{KB})$ \\
$\mathrm{X}<\bar{X}-1 \mathrm{SBi}$ & Sangat Kurang Baik & $(\mathrm{SKB})$ \\
\hline
\end{tabular}

Keterangan:

Mean ideal/rerata $(\bar{X})=1 / 2$ (skor tertinggi ideal + skor terendah ideal)

Simpangan baku skor ideal $\left(\mathrm{SB}_{\mathrm{i}}\right)=1 / 6$ (skor tertinggi ideal - skor terendah ideal)

(Mardapi, 2008: 123).

Berdasarkan Tabel 9. maka berikut pedoman penentuan tingkat keterampilan berpikir kreatif siswa berdasarkan data hasil observasi.

Tabel 10 Pedoman penentuan tingkat keterampilan berpikir kreatif siswa

\begin{tabular}{ccc}
\hline Skala & \multicolumn{2}{c}{ Kategori } \\
\hline$x \geq 18$ & Sangat Baik & $(\mathrm{SB})$ \\
$18>x \geq 15$ & Baik & (B) \\
$15>x \geq 12$ & Kurang Baik & (KB) \\
$x<12$ & Sangat Kurang & (SKB) \\
& Baik & \\
\hline
\end{tabular}

Berikut sebaran keterampilan berpikir kreatif siswa berdasarkan hasil observasi berdasarkan Tabel 10. 
Tabel 11. Sebaran keterampilan berpikir kreatif siswa

\begin{tabular}{cccccc}
\hline Skala & Kategori & \multicolumn{2}{c}{ KK } & \multicolumn{2}{c}{ KE } \\
& & Jumlah & $\%$ & Jumla & $\%$ \\
$x>18,84$ & SB & 19 & 76 & 24 & 9 \\
& & & & & 6 \\
$18,84<x \leq 14,28$ & B & 6 & 24 & 1 & 4 \\
$14,2<x \leq 9,72$ & CB & - & - & - & - \\
$9,72<x \leq 5,16$ & KB & - & - & - & - \\
$x \leq 5,16$ & SKB & - & - & - & - \\
\hline
\end{tabular}

Jika ditelaah lebih jauh, Tabel 11 menunjukkan bahwa siswa yang melakukan pembelajaran fisika berbasis potensi lokal memiliki tingkat keterampilan berpikir kreatif yang lebih baik dibanding siswa yang belajar fisika tanpa menggunakan potensi lokal sebagai basisnya. Gambar 3 berikut adalah data hasil observasi keterampilan berpikir kreatif seluruh siswa berdasarkan penilaian dari 2 observer.

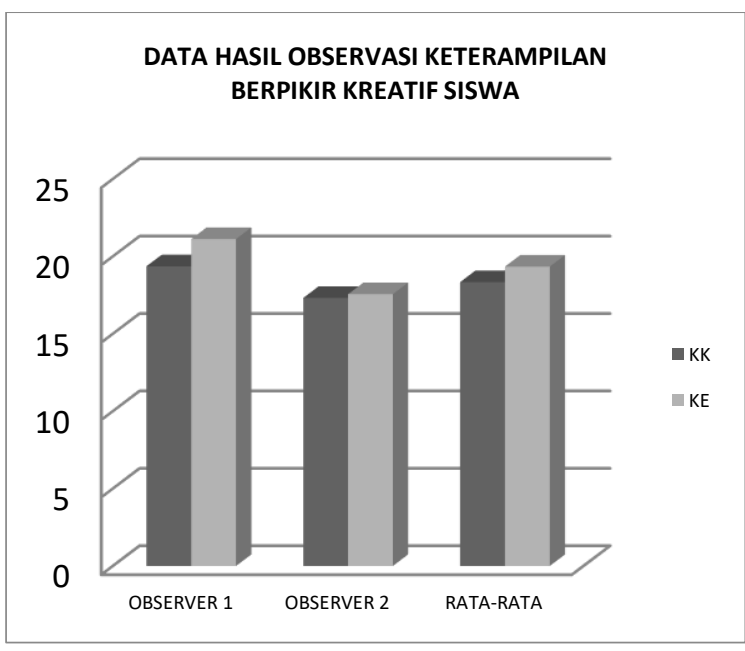

Gambar 3. Data hasil observasi keterampilan berpikir kreatif siswa di KK dan KE

\section{PEMBAHASAN}

Potensi lokal adalah potensi sumber daya spesifik yang dimiliki suatu daerah (Asmani, 2012). Potensi lokal meliputi sumber daya alam, sumber daya manusia, teknologi, dan budaya yang dapat dikembangkan untuk membangun kemandirian nasional (Hariyadi, 2010: 298). Potensi lokal dapat dimanfaatkan dalam banyak bidang, salah satunya pendidikan. Ada begitu banyak hasil penelitian tentang pemanfaatan potensi lokal dalam pendidikan. Suastra (2005) berhasil mengembangkan pendidikan sains yang mengintegrasikan budaya lokal di sekolah. Beberapa tahun kemudian, Suastra \& Nengah (2010) meneliti keefektifan model pembelajaran sains yang mengintegrasikan budaya lokal untuk mengembangkan kompetensi dasar dalam sains dan nilai kearifan lokal di SMP. Mungmachon (2012) meneliti tentang pemanfaatan pengetahuan dan potensi lokal untuk menyelesaikan masalah pembangunan di masyarakat. Sahlberg (2007) menuliskan keberhasilan Finlandia dalam memanfaatkan potensi alam untuk pembangunan ekonomi dan sosial melalui pendidikan. Zoller (2013) mengkaitkan potensi lokal dengan pendekatan SETS (science, environment, tecknology, and society) dengan harapan dapat meningkatkan HOTS (high order thinking). HOTS merupakan salah satu keterampilan yang diperlukan abad 21 untuk menyelesaikan permasalahan multidimensi, sistem sosial, ekonomi, teknologi, dan lingkungan. Hasil penelitian menunjukkan bahwa meskipun jalan menuju STES sulit, tetapi SETS mampu mencapai HOTS.

Pelaksanakan pembelajaran yang mengintegrasikan potensi lokal memerlukan model dan strategi yang cocok (Pornpimon, Wallapha, \& Prayuth, 2014; Agung, 2015). Suastra \& Nengah (2010); Kesiman \& Agustini (2012); Ardan, Ardi, \& Hala (2015) menyatakan bahwa sebelum dilakukan pembelajaran yang mengintegrasikan potensi lokal perlu dilakukan kegiatan menggali berbagai potensi lokal yang ada terlebih dahulu untuk kemudian diintegrasikan dengan materi pembelajaran. Hasil pengintegrasian dioperasionalkan dalam silabus, rencana pelaksanaan pembelajaran (RPP), bahan pembelajaran, pembelajaran, media dan lembar kerja siswa (LKS).

Meskipun telah banyak penelitian tentang pemanfataan potensi lokal dalam pembelajaran, namun belum ada hasil penelitian yang membahas mengenai pembelajaran fisika berbasis potensi lokal dalam meningkatkan keterampilan berpikir kreatif siswa. Penelitian ini merupakan 
penelitian lanjutan yang sebelumnya telah berhasil menyusun perangkat pembelajaran fisika yang mengintegrasikan potensi lokal meliputi silabus, RPP, dan LKS dan memenuhi unsur valid (Sarah \& Maryono, 2014). Penelitian kemudian dilanjutkan untuk mengetahui implementasi pembelajaran fisika yang mengintegrasikan potensi lokal pada siswa di tiga SMA dengan kategori tinggi, sedang, dan rendah. Kategori didasarkan pada kemampuan akademik siswa, akreditasi sekolah, dan usia sekolah. Hasilnya, sekolah dengan kategori tinggi membutuhkan waktu sesuai alokasi waktu yang ditentukan dalam RPP. Sebaliknya, sekolah dengan kategori sedang dan rendah membutuhkan alokasi waktu yang lebih banyak (Sarah \& Maryono, 2014). Kedua hasil penelitian di atas memberikan gagasan untuk melakukan penelitian lanjutan yaitu menerapkan pembelajaran yang mengintegrasikan potensi lokal dalam pembelajaran fisika hanya saja dengan variabel berbeda yaitu keterampilan berpikir kreatif. Ini dikarenakan, kegiatan pembelajaran fisika berbasis potensi lokal yang disusun ternyata sarat dengan peningkatan keterampilan berpikir kreatif.

Berpikir kreatif menurut Robson (2014: 122) yaitu proses berpikir untuk menemukan sesuatu yang baru untuk individu tersebut, yang belum ditemukan oleh orang lain. Udi \& Amit (2011: 1088); Meintjes \& Grosser (2010: 362); dan Erdogan, Akkaya \& Akkaya, (2009: 185) menyatakan bahwa berpikir kreatif memungkinkan pemecahan masalah di berbagai bidang, menciptakan solusi yang inovatif, asli, dan berkualitas. Berpikir kreatif ditandai dengan fleksibilitas, rasa ingin tahu, imajinasi yang berkembang dengan baik, tertarik dalam menemukan solusi, penciptaan metafora, dan berorientasi pada tujuan pemikiran. Berbeda dengan beberapa ahli sebelumnya, Bakir \& Oztekin (2014: 232) menyatakan bahwa berpikir kreatif melibatkan proses berpikir divergen. Vari (2015: 76) menambahkan bahwa berpikir kreatif penting sebagai dasar dalam melakukan penelitian/penyelidikan.

Hencer (2013: 241) mengemukakan bahwa berpikir kreatif meliputi sikap, pengetahuan, dan keterampilan. Berpikir kreatif penting bagi peserta didik dalam semua aspek mencakup sikap seperti imajinatif, rasa ingin tahu, keterbukaan, objektivitas, fleksibilitas, kelancaran, kepekaan terhadap rangsangan sensorik, humor, kesediaan untuk mencoba ide-ide baru, terampil, dan kemampuan untuk bekerja secara intensif untuk jangka waktu yang lama (Piaw, 2010: 551-552). Adapun Kandemir \& Gur (2009: 1629) menyatakan bahwa berpikir kreatif dapat dikembangkan menggunakan kreativitas dan teknik pemecahan masalah secara kreatif. Indikator berpikir kreatif menurut Wright (2010: 5) meliputi 7 aspek. (1) Penemuan dan pemecahan masalah, yaitu menemukan dan mengeksplorasi tujuan alternatif dan pendekatan untuk masalah. (2) Keluwesan, yaitu mengambil pendekatan yang berbeda untuk memecahkan masalah, memikirkan ideide dalam berbagai cara atau melihat masalah dari perspektif lain. (3) Kelancaran, yaitu memproduksi banyak ide yang mengalir untuk menyelesaikan masalah atau pertanyaan. (4) Elaborasi, artinya menambahkan rincian ide meliputi pengembangan dan meningkatkan ide. (5) Transformasi artinya mengubah satu objek atau ide ke ide lain dengan menambahkan, mengurangkan, dan menukar. (6) Objektivitas dan selektivitas, yaitu menghasilkan ide-ide untuk membedakan mana ide-ide yang terbaik dan layak digunakan. (7) Apresiasi estetika, yaitu berjuang untuk sesuatu yang memiliki tujuan, hasil, dan standar tinggi. Adapun Fauziah (2011: 100) menyatakan bahwa indikator berpikir kreatif ada 3 (tiga). (1) Kelancaran (fluency) yaitu kemampuan mengeluarkan banyak ide atau gagasan yang beragam dengan melihat dari berbagai sudut pandang. (2) Keaslian atau orisinalitas (originalitas) yaitu kemampuan mengeluarkan ide atau gagasan yang unik dan tidak biasanya (yang berbeda dari pendapat orang lain). (3) Merinci atau elaborasi (elaboration), yaitu kemampuan menjelaskan faktor-faktor yang mempengaruhi gagasannya sehingga lebih bernilai. Ahli lain, yaitu Lai \& Viering $(2012,15)$ menyatakan bahwa kreatif berkaitan dengan faktor-faktor kognitif dan afektif. Komponen faktor kognitif 
mengacu kepada pengetahuan untuk mengakuisis atau proses kognitif yang terjadi ketika peserta didik menghadapi permasalahan. Komponen faktor afektif yaitu asosiasi positif kepada orang lain dalam menghadapi permasalahan yang diberikan. Dengan demikian ciri-ciri berpikir kreatif meliputi keterampilan mengidentifikasi permasalahan, menghasilkan ide, berpikir divergen dengan berpikir secara lancar, luwes, elaboratif, asli, dan pada akhirnya mampu menyelesaikan permasalahan. Piaw (2010: 553) mendefinisikan ciri-ciri berpikir kreatif meliputi menghasilkan ide-ide unik, menghasilkan ide-ide yang tidak biasa, mengambil sudut pandang yang berbeda, imajinatif, orientasi estetika, memahami keindahan seni, potensial dalam menghasilkan ide-ide, mampu menghasilkan banyak ide dalam satu waktu, kecenderungan melihat masalah dari berbagai perspektif, tidak terjebak dengan asumsi aturan yang tidak berlaku untuk masalah, cenderung melanggar aturan, perlu beberapa ruang bebas untuk inkubasi di tengah-tengah proses kreatif, bersifat terbuka dan membuat lompatan mental yang melebihi batas bebas, mampu menangkap esensi dari informasi yang diberikan, imajinatif, berpikir abstrak tapi tepat, mampu berkomunikasi dengan jelas dan kuat melalui cerita, berfantasi (fantasi menyediakan pasokan dari analogi dalam memecahkan masalah secara kreatif) seperti melamun dan emosional, cenderung menggabungkan dua unsur menjadi satu, kerja dinamis, kemampuan untuk memperluas dan melanggar batas-batas masalah, dan rasa humor yang baik (humor pada dasarnya kreatif karena melibatkan sesuatu yang tidak biasa dan mengejutkan). Khusus dalam pembelajaran fisika, indikator berpikir kreatif menurut Tawil \& Liliasari (2013: 67) di antaranya mengembangkan pengetahuan yang dimiliki oleh peserta didik, membangkitkan keingintahuan peserta didik, memandang informasi dari sudut pandang yang berbeda, memprediksi informasi yang terbatas, merumuskan masalah, merumuskan hipotesis yang berdasarkan fenomena yang diamati, dan menguji hipotesis.
Hasil penelitian menunjukkan bahwa pembelajaran berbasis potensi lokal pada basan mengenai fluida statis dapat meningkatkan keterampilan berpikir kreatif siswa. Jika ditelisik lebih jauh, pembelajaran berbasis potensi lokal yang dikembangkan menggunakan desain pembelajaran inkuiri terbimbing yang dipadu dengan kegiatan praktikum. Potensi lokal yang digunakan yaitu belerang yang ada di Kawah Sikidang, Pegunungan Dieng. Belerang dijadikan sebagai bahan praktikum tentang viskositas larutan belerang. Pada awal kegiatan, siswa merasa bingung dalam melakukan praktikum. $\mathrm{Hal}$ ini dikarenakan praktikum yang dilaksanakan bagi siswa berbeda dari yang selama ini dilakukan. Kegiatan yang menurut siswa susah yaitu saat diminta untuk menentukan hipotesis. Siswa kebingungan karena belum terbiasa membaca bahan pelajaran secara mandiri. Siswa terbiasa menerima apa yang didapat dari guru. Kesulitan tidak terjadi di langkah ini saja. Saat melakukan praktikum, siswa belum paham apa yang harus dilakukan. Padahal masing-masing siswa sudah memiliki buku petunjuk praktikum. Akhirnya, guru pun membacakan dan menjelaskannya. Kendala lainnya yaitu saat menganalisis data dan melakukan presentasi. Kendala-kendala tersebut menjadikan waktu yang diperlukan untuk melakukan praktikum lebih banyak dibandingkan alokasi waktu yang ditentukan. Pada percobaan ke 2 kendala yang ada sudah jauh berkurang. Siswa sudah mulai tertib dan kondusif dalam melakukan praktikum.

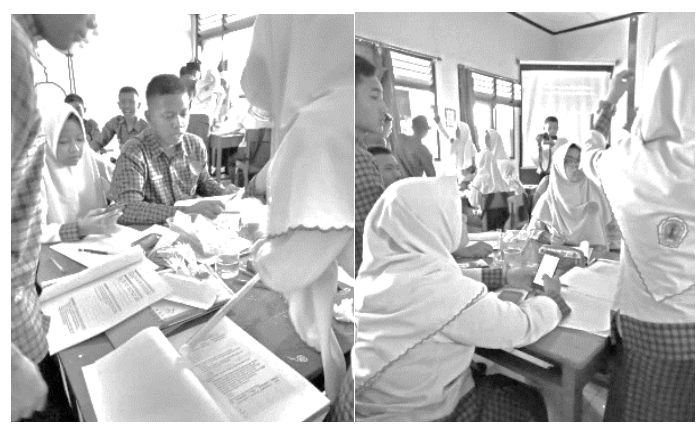

Gambar 4. Siswa sedang melakukan pratikum 


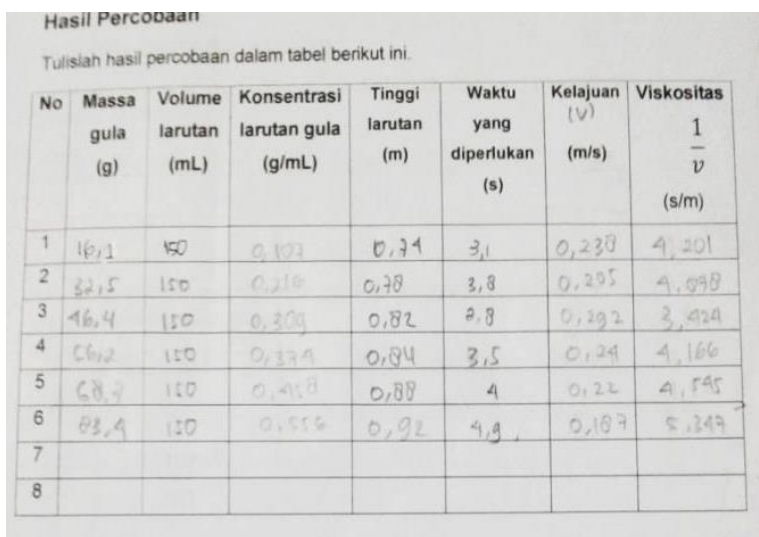

(a)

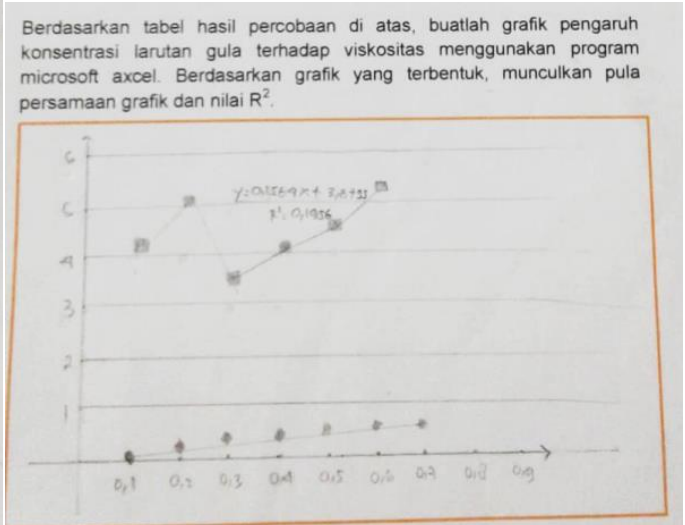

(b)

Gambar 5 (a) dan (b) hasil analisis data percobaan siswa

Pada Gambar 5 (b) terlihat siswa belum terampil menggambar grafik hasil praktikum menggunakan program excel yang sebelumnya telah diajarkan. Hal ini menjadikan siswa kesulitan dalam menjawab pertanyaan yang menyatakan hasil analisis grafik.

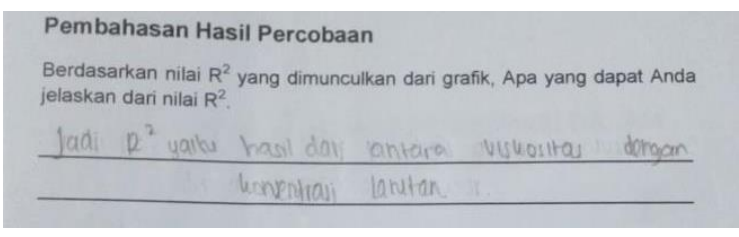

Gambar 6: Pembahasan hasil percobaan

Melalui pembelajaran fisika berbasis potensi lokal ini, siswa dapat meningkatkan keterampilan berpikir kreatif yang salah satu indikatornya tercermin dari grafik yang terbentuk beserta analisisnya. Pembuatan grafik beserta analisis grafik merupakan salah satu indikator keterampilan berpikir kreatif yaitu siswa dapat menyelesaikan masalah yaitu mampu mengetahui pengaruh konsentrasi belerang terhadap viskositas larutan belerang.

\section{PENUTUP}

Berdasarkan hasil penelitian diketahui bahwa ada peningkatan keterampilan berpikir kreatif siswa yang belajar fisika menggunakan perangkatan pembelajaran berbasis potensi lokal. Hal ini dapat dilihat dari hasil uji gain ternormalisasi sebesar 0,15975 dengan kategori rendah.

\section{DAFTAR PUSTAKA}

Agung, S. L (2015). The Development of Local Wisdom-Based Social Science Learning Model with Bengawan Solo as the Learning Source. American International Journal of Social Science. 4(4), 51-58.

Asmani, J. M. (2012). Pendidikan Berbasis Keunggulan Lokal. Yogyakarta: DIVA Press.

Ardan, A. S., Ardi, M., \& Hala, Y. (2015). Needs Assessment to Development of Timor. International Education Studies;8(4). https://doi.org/10.5539/ies.v8n4p52.

BPS (Badan Pusat Statistik). 2018. Keadaan Ketenagakerjaan Indonesia Februari 2018. No. 42/05/Th. XXI, 07 Mei 2018.

Pornpimon, C., Wallapha, A., \& Prayuth, C. (2014). Strategy challenges the local wisdom applications sustainability in schools. Procedia-Social and Behavioral Sciences, 112, 626-634. https://doi.org/10.1016/i.sbspro.2014.01. $\underline{1210 .}$.

Collette, A. T. \& Chiappette, E. L. (1994). Science Instruction in The Middle and Secondary Schools. New York: Macmillan Publishing Company. 
Bakır, S., \& Öztekin, E. (2014). Creative thinking levels of preservice science teachers in terms of different variables. Journal of Baltic Science Education, 13(2), 231-242.

Erdogan, T., Akkaya, R., \& Celebi Akkaya, S. (2009). The Effect of the Van Hiele Model Based Instruction on the Creative Thinking Levels of 6th Grade Primary School Students. Educational sciences: theory and practice, 9(1), 181-194.

Fauziah, Y. N. (2011). Analisis Kemampuan Guru dalam Mengembangkan Keterampilan Berpikir Kreatif Siswa Sekolah Dasar Kelas V pada Pembelajaran IImu Pengetahuan Alam. Jurnal Edisi Khusus, 1(1), 98-106.

Giancoli, D. C. (2011). Fisika: Prinsip dan Aplikasi Edisi Ketujuh 1 Jilid 1. (Terjemahan Irzam Hardiansyah). Erlangga: Jakarta.

Hake, R. R. (1998). Interactive-engagement versus traditional methods: A sixthousand-student survey of mechanics test data for introductory physics courses. American journal of Physics, 66(1), 64-74. https://doi.org/10.1119/1.18809

Hariyadi, P. (2010). Penguatan Industri Penghasil Nilai Tambah Berbasis Potensi Lokal peranan Teknologi Pangan untuk Kemandirian Pangan. Jurnal PANGAN,19(4).

Hariyadi, P. (2010). Penguatan Industri Penghasil Nilai Tambah Berbasis Potensi Lokal peranan Teknologi Pangan untuk Kemandirian Pangan. PANGAN, 19(4), 295-301.

Hencer, A. H. (2013). The Correlation Between the Scientific Process and Creative Thinking Skills of the Preservice Teachers. International Journal of Academic Research, 5(3), 240-246.

Kandemir, M. A., \& Gür, H. (2009). The use of creative problem solving scenarios in mathematics education: views of some prospective teachers. Procedia-Social and Behavioral Sciences, 1(1), 16281635.

https://doi.org/10.1016/i.sbspro.2009.01. $\underline{286}$.

Kesiman, M. W. A. \& Ketut, A. (2012). The Implementation of Hypertext-based Learning Media for a Local Cultural Based Learning. Journal of Information Technology Education: Innovations in Practice, $\quad 11, \quad 377-385$. http://www.jite.org/documents/Vol11/JITE v11IIPp377-365Kesiman1115.pdf.

Klieger, A. \& Sherman, G. 2015. Physics textbooks: do they promote or inhibit students' creative thinking. Physics Education 50(3), 305-309. https://doi.org/10.1088/0031$\underline{\text { 9120/50/3/305 }}$

Lai, E. R. \& Viering, M. (2012). Assessing $21^{\text {st }}$ Century Skill: Integrating Research Findings. National Council on Measurement in Education. Person. 166.

Mardapi, D. (2008). Teknik Penyusunan Instrumen Tes dan Nontes. Yogyakarta: Mitra Cendekia Press.

Meintjes, H. \& Grosser, M. (2010). Creative Thinking in Prospective Teachers: the Status Quo and The Impact of Contextual Factors. South African Journal of Education, 30(3), 361-386. http://dx.doi.org/10.15700/saje.v30n3a3 $\underline{60}$.

Mungmachon, R. (2012). Knowledge and Local Wisdom: Community Treasure. International Journal of Humanities and Social Science, 2(13), 174-181.

Piawa, C. Y. (2010). Building a test to assess creative and critical thinking simultaneously. Procedia-Social and Behavioral Sciences, 2(2), 551-559. https://doi.org/10.1016/i.sbspro.2010.03. $\underline{062}$.

Robson, S. (2014). The Analysing Children's Creative Thinking framework: development of an observation-led approach to identifying and analysing young children's creative thinking. British Educational Research 
Journal, 40(1),

121-134. https://doi.org/10.1002/beri.3033.

Sahlberg, P. (2007). Education Policies For Raising Student Learning: The Finnish Approach. Journal of Education Policy, 22(2), 147171.

https://doi.org/10.1080/0268093060115 $\underline{8919}$.

Sarah, S. \& Maryono (2014). Pengembangan Perangkat pembelajaran Berbasis Potensi Lokal untuk Meningkatkan Living Values Peserta Didik SMA di Kabupaten Wonosobo. Technoscientia, 6(2), 185-194.

Sarah, S. \& Maryono. (2014). Keefektivan Pembelajaran Berbasis Potensi Lokal dalam Pembelajaran Fisika SMA dalam Meningkatkan Living Values. Jurnal Pendidikan Sains, 2(1), 36-42.

Scheider, W. (1980). 27 commandments for physics teachers. The Physics Teacher, 18(1), 32-33. https://doi.org/10.1119/1.2340404.

Suastra, I. W. (2005). Reconstruct the original Science (Indigenous Science) in order to develop local cultural-based science education in schools: Etnosains Study on Community Penglipuran Bali (Unpublished dissertation). Bandung: Graduate Education University of Indonesia.

Suastra, I. W. dan Nengah. (2010). Sciencebased models of local culture to develop Basic Competence in science and value of local wisdom in junior high School. Journal of education and the teaching of State Univ. Singaraja, 43(2), 8-16.

Tawil, M., \& Liliasari. (2013). Berpikir Kompleks dan Implementasinnya dalam Pembelajaran IPA. Makasar: Badan Penerbit UNM.

Trilling, B., \& Fadel, C. (2009). 21st Century Skills, Learning for Life in Our Times. San Francisco, CA: John Willey \& Sons.

Udi. E. A., \& Amit, M. (2011). Developing the Skills of Critical and Creative Thinking by Probability Teaching. Procedia Social and Behavioral Science, 15, 1087-1091.

Vari, S. G. (2015). Key elements of networking in life sciences: collective creative thinking and team work. Croatian medical journal, 56(2), 75-77. https://dx.doi.org/10.3325\%2Fcmj.2015. $\underline{56.75 .}$.

Wright, S. (2010). Understanding Creativity in Early Childhood Meaning-Making and Children's Drawings. London ECIY 1 SP: Sage Publications Ltd.

Zoller, U. (2013). Science, technology, environment, society (STES) literacy for sustainability: what should it take in chem/science education?. Educación Química, 24(2), 207-214. https://doi.org/10.1016/S0187893X(13)72464-9 